\title{
PENGARUH TAX AVOIDANCE DAN BIAYA AGENSI TERHADAP NILAI PERUSAHAAN DENGAN KUALITAS AUDIT SEBAGAI VARIABEL MODERASI PADA PERUSAHAAN LQ45
}

\author{
Warno1, Ulul Fahmi² \\ Fakultas Ekonomi dan Bisnis Islam UIN Walisongo Semarang ${ }^{1,2}$ \\ Jalan Prof. Dr. H. Hamka Kampus 3 Ngaliyan Semarang, 50185, Indonesia \\ e-mail:ululfahmi43@yahoo.com²
}

\begin{abstract}
This study aims to examine the influence of tax avoidance andcosts agencyon firm value and wants to test audit quality in strengthening and weakening the relationship between tax avoidance and firm value. The population in this study are companies listed in the LQ45 index in theEffect Exchange Indonesia2016-2018 period. Sampling in this study was carried out using purposive sampling with a total sample of 90 companies in a period of three years. This study uses a quantitative approach by using the SEM-PLS analysis method using WarpPLS 4.0 software. The results ofstudy this indicate that the variable tax avoidance that is projected using CashETR and agency costs projected with sales to total assets (STA) significantly influence the value of the company that is projected with Tobins'Q. The results of this study also show that the audit quality projected by bigfournot canweaken or strengthen the relationship that occurs between tax avoidance on firm value.
\end{abstract}

Keywords: Tax Avoidance, Agency Cost. Firm Value, Audit Quality.

\begin{abstract}
Abstrak
Penelitian ini bertujuan untuk untuk menguji adanya pengaruh tax avoidance dan biaya agensi terhadap nilai perusahaan serta ingin menguji kualitas audit dalam memperkuat maupun memperlemah hubungan antara tax avoidance dengan nilai perusahaan. Populasi dalam penelitian ini adalah perusahaan yang terdaftar dalam Indeks LQ45 yang ada di Bursa Effek Indonesia periode 2016-2018. Pengambilan sampel dalam penelitian ini dilakukan dengan menggunakan purposive sampling dengan total sampel sebanyak 90 buah perusahaan dalam kurun waktu tiga tahun. Penelitian ini menggunakan pendekatan kuantitatif dengan dengan menggunakan metode analisis SEM-PLS menggunakan software WarpPLS 4.0. Hasil penelitian ini menunjukkan bahwa variabel tax avoidance yang diproyeksikan dengan menggunakan CashETR dan biaya agensi yang diproyeksikan dengan Sales to Total Asset (STA) berpengaruh secara signifikan terhadap nilai perusahaan yang diproyeksikan dengan Tobins' $\mathbf{Q}$. Hasil penelitian ini juga menunjukkan bahwa kualitas audit yang diproyeksikan dengan bigfour tidak dapat memperlemah maupun memperkuat hubungan yang terjadi antara tax avoidance terhadap nilai perusahaan.
\end{abstract}

Kata Kunci: Tax avoidance, biaya agensi, nilai perusahaan, kualitas audit.

\section{PENDAHULUAN}

Revolusi industri 4.0 memberikan dampak pada seluruh aspek kehidupan tidak terkecuali pada kehidupan bisnis. Perusahaan harus mampu beradaptasi, bersaing, dan mengikuti perubahan untuk tetap bisa survive dalam menjalankan usahanya dan meningkatkan nilai perusahaannya. Perusahaan mempunyai tujuan untuk meningkatkan nilai perusahaannya.

Nilai perusahaan yang baik dapat tercermin dari harga pasar saham yang beredar di pasaran (Basri, Agusti, \& Adelina, 2014: 1). Harga saham yang semakin tinggi akan diikuti dengan semakin tingginya nilai perusahaan (Febriana, Djumahir, \& Djawahir, 2016: 1). Peningkatan terhadap nilai perusahaan dapat tercapai apabila pelaksanaan fungsi manajemen dilakukan dengan baik. Terdapat banyak cara untuk dapat EL MUHASABA Volume 11, No. 2, Tahun 2020|188 
Warno dan Ulul Fahmi: Pengaruh Tax Avoidance dan Biaya Agensi terhadap Nilai Perusahaan dengan Kualitas Audit sebagai Variabel Moderasi pada Perusahaan yang Terdaftar di Indeks LQ45 Periode 2016-2018

meningkatkan nilai perusahaan yang bisa diambil olem manajemen. Salah satunya yaitu dengan cara mengefisiensikan beban pajak yang dibayarkan oleh perusahaan.

Berdasarkan pasal 1 ayat 1 Undang-Undang No. 28 tahun 2007 tentang Ketentuan Umum dan Tata Cara Perpajakan menyatakan bahwa "pajak adalah kontribusi wajib kepada negara yang terutang oleh orang pribadi atau badan yang bersifat memaksa berdasarkan Undang-Undang dengan tidak mendapatkan imbalan secara langsung dan digunakan untuk keperluan negara bagi sebesar-besarnya kemakmuran rakyat". Berdasarkan data Badan Pusat Statistik (BPS), realisasi penerimaan negara pada tahun 2018 yang berasal dari pajak sebesar 1,548.5 Triliun atau sekitar 81,3\% dari total penerimaan negara pada tahun 2018 sebesar 1,903 Triliun. Besarnya penerimaan dari sektor pajak bukan berarti mengindikasikan bahwa penerimaan pajak sudah maksimal.

Penerimaan pajak belum optimal salah satunya disebabkan karena adanya aktivitas perusahaan dalam mengurangi beban pajak yang dikeluarkan kepada negara yang akan bertujuan untuk meningkatkan laba setelah pajak perusahaan. Salah satunya adalah dengan melakukan tax avoidance atau pernghindaran pajak. Menurut Pohan (2013) yang dikutip dari Putri, tax avoidance merupakan suatu strategi atau cara untuk menghidari pajak secara legal dan aman yang dilakukan oleh wajib pajak karena tidak bertentangan dengan peraturan perpajakan (Putri, 2017: 23).

Kasus penghindaran pajak (tax avoidance) terjadi pada Adaro Energy (Persero) Tbk. Berdasarkan laporan dari Global Witness yang merupakan LSM Internasional yang bergerak dalam isu lingkungan hidup melaporkan adanya dugaan penghindaran pajak yang dilakukan oleh Adaro Energy (Persero) Tbk. Perusahaan yang bergerak dalam bidang pertambangan batu bara terbesar di Indonesia diindikasikan melakukan transfer pricing dengan cara melarikan pendapatan dan labanya ke anak perusahaan di Singapura bernama Coaltrade Service Internasional kemudian dijual kembali ke negara lain dengan harga yang mahal sehingga membuat pendapatan perusahaan tinggi namun pajak yang disetorkan ke negara menjadi rendah. Global Witness menemukan dugaan pembayaran pajak yang dibayarkan oleh PT Adaro Energy Tbk, yang lebih rendah dari yang seharusnya dibayarkan kepada pemerintah Indonesia sebesar 125 juta dolar AS atau setara dengan $\operatorname{Rp} 1,75$ Triliun apabila kurs rupiah di angka $\operatorname{Rp} 14,000$. (www.finance.detik.com, diakses pada 19 Desember 2019).

Untuk dapat mencapai tujuan dari perusahaan yaitu meningkatkan nilai perusahaan harus ada sinergi yang baik antara manajemen (agent) dan pemegang saham (Principal). Namun sering kali manajemen dan pemilik saham mengutamakan kepentingannya sendiri atau mengedepankan perilaku oportunistik. Hal tersebut mengakibatkan konflik keagenan. Konflik keagenan dapat diminimalisir dengan biaya agensi. Menurut Jensen dan Meckling (1976) yang dikutip dari Sintyawati dan Dewi, menjelaskan bahwa biaya agensi adalah biaya yang ditanggung oleh pemegang saham perusahaan guna mengatur dan mengawasi kinerja manajemen agar kinerjanya sesuai dengan kepentingan perusahaan (Sintyawati \& Dewi, 2018: 995). Dengan adanya biaya agensi akan dapat memonitoring pekerjaan dari manajer agar sesuai dengan kontrak yang telah disepakati kedua belah pihak. Adanya biaya agensi akan dapat membatasi kecurangan yang bisa dilakukan sehingga akan menstimulus tercapainya tujuan perusahaan yaitu meningkatkan nilai perusahaan. 
Warno dan Ulul Fahmi: Pengaruh Tax Avoidance dan Biaya Agensi terhadap Nilai Perusahaan dengan Kualitas Audit sebagai Variabel Moderasi pada Perusahaan yang Terdaftar di Indeks LQ45 Periode 2016-2018

Untuk mengatasi penurunan nilai perusahaan yang disebabkan oleh perilaku tax avoidance perlu adanya tata kelola perusahaan yang baik. Ada beberapa item untuk mengukur tingkat tata kelola perusahaan yang baik. Salah satunya bisa dilihat dalam hal kualitas audit. Menurut Maharani dan Suardana menjelaskan bahwa kualitas audit merupakan semua kemungkinan yang bisa terjadi ketika auditor melakukan audit atas laporan keuangan klien dan mendapatkan temuan pelanggaran atau kesalahan dan mengemukakannya pada laporan keuangan auditan (Maharani \& Suardana, 2014: 529530). Auditor diharapkan dapat mempekecil peluang terjadinya asimetri informasi dan mengurangi perilaku penghindaran pajak yang dilakukan oleh perusahaan (Krisna, 2019: 3). Adanya audit yang berkualitas akan memperkecil kemungkinan manajer dalam melakukan tax avoidance terhadap perusahaan. Penelitian yang dilakukan Rusli pada tahun 2016 menghasilkan kualitas audit sebagai variabel moderasi dapat melemahkan hubungan yang terjadi antara tarif pajak efektif terhadap nilai perusahaan (Ningrum \& Lestaria, 2018: 100). Penelitian tersebut didukung oleh penelitian yang dilakukan oleh Wardani dan Juliani pada tahun 2018 yang menyatakan bahwa kualitas audit mampu memoderasi atau memperlemah hubungan antara tax avoidance terhadap nilai perusahaan (Wardani \& Juliani, 2018: 59). Namun tidak sesuai dengan penelitian yang dilakukan oleh Lestari dan Ningrum pada tahun 2018 yang menunjukkan bahwa kualitas audit yang semakin buruk atau semakin baik tidak mempengaruhi hubungan yang terjadi antara tax avoidance dengan nilai perusahaan.

Penelitian tentang tax avoidance, biaya agensi, dan nilai perusahaan masih menunjukkan hasil yang beragam. Seperti penelitian yang dilakukan oleh Anggoro dan Septiani (2015) dijelaskan bahwa perilaku penghindaran pajak yang dilakukan perusahaan memberikan pengaruh yang signifikan terhadap nilai perusahaan dengan arah positif sehingga dari hasil penelitiannya bisa disimpulkan bahwa dengan adanya tax avoidance akan meningkatkan nilai perusahaan. Berbeda dari penelitian-penelitian tersebut, penelitian yang dilakukan oleh Apsari dan Setiawan pada tahun 2008 yang menyimpulkan bahwa tax avoidance yang tinggi akan mengakibatkan nilai perusahaan turun sebab dengan adanya tax avoidance akan menyebabkan citra perusahaan menjadi buruk karena dianggap tidak patuh terhadap negara dan memberikan informasi yang menyesatkan kepada investor (Apsari \& Setiawan, 2018: 1785).

Penelitian ini merupakan pengembangan dari penelitian dari Anggoro dan Septiani (2015). Dengan perbedaan yang terletak pada alat ukur, sampel, tahun penelitian, dan variabel moderasi. Penelitian yang dilakuka oleh Anggoro dan Septiani menggunakan Book Tax Different (BTD) untuk mengukur tax avoidance sedangkan dalam penelitian ini menggunakan Cash Effective Tax Ratio (CETR), sampel yang diuji pada penelitian tersebut adalah perusahaan manufaktur sedangkan penelitian ini menggunakan sampel yang terdiri dari beberapa jenis perusahaan, tahun penelitian yang dilakukan oleh Anggoro dan Septiani mulai dari tahun 2010 hingga 2013 sedangkan penelitian ini memakai tahun penelitian 2016 hingga tahun 2018, dan variabel moderasi transparansi dalam penelitian Anggoro dan Septiani diganti dengan kualitas audit. Oleh sebab itu, dengan adanya penelitian ini diharapkan didapatkan hasil yang lebih luas untuk dapat digunakan dalam meningkatakan informasi terkait keadaan pajak yang ada di Indonesia. Berdasarkan adanya perbedaan yang telah dipaparkan membuat penulis 
Warno dan Ulul Fahmi: Pengaruh Tax Avoidance dan Biaya Agensi terhadap Nilai Perusahaan dengan Kualitas Audit sebagai Variabel Moderasi pada Perusahaan yang Terdaftar di Indeks LQ45 Periode 2016-2018

tertarik ingin melakukan penelitian Pengaruh Tax Avoidance dan Biaya Agensi Terhadap Nilai Perusahaan Dengan Kualitas Audit Sebagai Variabel Moderasi Pada Perusahaan Yang Terdaftar di Indeks LQ45 Periode 2016-2018.

\section{KAJIAN PUSTAKA}

\section{Teori Agensi}

Teori agensi merupakan teori yang membahas tentang hubungan antara agent dan principal. Menurut Jensen dan Meckling (1976), mendefinisikan hubungan keagenan sebagai kontrak yang terjadi antara satu orang atau lebih yang terdiri dari principal sebagai pemberi kerja dan agent yang dipekerjakan guna melaksanakan serangkaian pekerjaan dan memberikan wewenang kepada agent untuk mengambil keputusan (Jensen \& Meckling, 1976: 308). Menurut Bringham \& Houston (2006) yang dikutip dari Prasiwi, pemilik memberikan kekuasaan kepada agent untuk membuat keputusan namun hal ini bisa saja menimbulkan konflik keagenan yang sering dinamakan sebagai teori agensi (Prasiwi, 2015: 16). Agent sebagai pengelola perusahaan mempunyai informasi yang lebih terkait dengan kondisi perusahaan sehingga bisa saja tidak mengungkapkan informasi yang ada di perusahaan kepada pihak eksternal. Hal tersebut akan meningkatkan perilaku oportunistik atau mementingkan kepentingan pribadi dari agent.

\section{Nilai Perusahaan (Firm Value)}

Perusahaan memiliki tujuan-tujuan tertentu yang hendak dicapai baik itu tujuan untuk perusahaan yang sifatnya jangka pendek maupun jangka panjang. Menurut Salvatore (2005) yang dikutip dari Sibarani, salah satu tujuan dari adanya suatu perusahaan adalah untuk memaksimalkan nilai perusahaan (Sibarani, 2016: 10). Apabila nilai perusahaannya tinggi, investor akan dengan senang hati membeli surat berharga dengan harga tinggi (Ningtias, 2015: 25). Nilai perusahaan menjadi salah satu indikator tingkat keberhasilan suatu perusahaan dalam lingkungan bisnis. Nilai perusahaan yang tinggi akan menjadikannya dipercaya oleh pasar terkait kinerjanya yang sekarang dan di masa depan. Nilai perusahaan dapat menggambarkan kesejahteraan kepada kepada pemilik (Ary Wirajaya, 2013: 361).

Dalam perspektif Islam, nilai perusahaan dikaitkan dengan prinsip-prinsip syariah. Dalam prinsip syariah upaya untuk meningkatkan nilai perusahaan yang bertujuan untuk mencari keuntungan tidak boleh terdapat unsur maysir, gharar, dan riba yang hukumnya tidak boleh dalam syariat Islam (Rani Novitasari, 2018: 41). Allah telah melarangnya dalam Q.S Al Maidah ayat 90, yang artinya:

"Hai orang-orang yang beriman, sesungguhnya (meminum) khamar, berjudi, (berkorban untuk) berhala, mengundi nasib dengan panah adalah termasuk perbuatan syaitan. Maka jauhilah perbuatan-perbuatan itu agar kamu mendapat keberuntungan." (Q.S Al-Maidah: 90).

Ayat di atas menjelaskan bahwa judi merupakan suatu hal yang diharamkan. Setiap permainan dimana sifatnya menghilangkan tempo, melalaikan waktu, serta adanya pertaruhan di dalamnya tidak diperbolehkan (Hamka, 2015: 25). Ayat di atas menjelaskan bahwa perjudian bisnis atau spekulasi yang dilakukan oleh perusahaan untuk meningkatkan nilai perusahaan yang ujungnya akan memperoleh nilai baik di mata investor terhadap perusahaan merupakan suatu bagian dari maysir (Megarani, 
Warno dan Ulul Fahmi: Pengaruh Tax Avoidance dan Biaya Agensi terhadap Nilai Perusahaan dengan Kualitas Audit sebagai Variabel Moderasi pada Perusahaan yang Terdaftar di Indeks LQ45 Periode 2016-2018

Fauzi, \& Warno, 2019: 148). Perbuatan tersebut dilarang oleh Islam karena akan ada pihak yang terdzalimi.

\section{Pajak}

Menurut Prof. Dr. P.J.A. Andriani yang dikutip dari Purwono, pajak merupakan suatu iuran yang diberikan kepada negara yang sifatnya memaksa oleh mereka yang terutang dan wajib untuk membayar sesuai dengan peraturan tanpa adanya imbal balik secara langsung untuk memenuhi kebutuhan negara dalam rangka menyelenggarakan pemerintahan (Purwono, 2010: 7). Tanpa ada kontribusi dari rakyat dalam hal pembayaran pajak, maka suatu negara tidak bisa berjalan dengan baik (Purwanti \& Sugiyarti, 2017: 1625).

Pajak merupakan hal yang sangat penting bagi negara sebab dengan adanya pajak yang besar penerimaan negara jadi besar. Namun di sisi lain pengeluaran pajak yang besar menjadikan beban tersendiri untuk perusahaan, sebab dengan membayar pajak akan mengurangi laba perusahaan sedangkan perusahaan sendiri menginginkan laba atau return yang besar. Oleh karena itu manajer selalu berupaya untuk mengecilkan beban pajak perusahaan.

\section{Perencanaan Pajak (Tax Planning)}

Perencanaan pajak diartikan sebagai salah satu cara dalam melakukan manajemen perpajakan. Menurut Pardiat (2009) yang dikutip dari Musyarofah, perencanaan pajak adalah suatu usaha yang dilakukan guna meminimalkan baban pajak setiap tahun tanpa melanggar ketentuan peraturan perpajakan yang berlaku, dengan menggunakan metode yang cepat, menggunakan fasilitas perpajakan atau stimulus perpajakan dan memanfaatkan adanya celah dari peraturan perpajakan (Musyarofah, 2016: 20). Ada beberapa manfaat dari perencanaan pajak yaitu: dapat menghemat kas keluar dapat mengatur aliran kas masuk dan keluar (Pohan, 2013: 20).

\section{Penghindaran Pajak (Tax Avoidance)}

Menurut Darussalam dkk (2009) yang dikutip dari Nurjannah, tax avoidance merupakan suatu strategi transaksi yang digunakan untuk mengecilkan beban pajak dengan cara mengambil kesempatan dengan adanya kelemahan-kelemahan (loopholes) dari peraturan perpajakan yang berlaku sehingga hal tersebut dapat dikatakan legal sebab tidak melanggar peraturan perpajakan (Nurjannah, 2017: 37-38).

Tax avoidance merupakan suatu akal-akalan pajak yang digunakan untuk mengurangi beban pajak yang dibayarkan seharusnya. Padahal Allah menyebutkan dalam Q.S An-nisa (4) yang artinya:

"Hai orang-orang beriman, janganlah kamu saling memakan harta sesamamu dengan jalan yang batil, kecuali dengan jalan perniagaan yang berlaku dengan suka sama suka diantara kamu. Dan janganlah kamu membunuh dirimu,sesungguhnya Allah adalah Maha Penyayang kepadamu".

Dalam ayat tersebut menjelaskan bahwa kita tidak boleh memakan harta sesama dengan jalan yang bathil. Bathil yang dimaksud adalah dengan mengambil manfaat suatu benda dengan cara yang dzalim tanpa mengganti harga yang semestinya dan hal itu tidak diperbolehkan (Az-Zuhaili, 2016: 57). Tax avoidance sama saja dengan perbuatan memakan harta sesama secara batil, karena dengan sengaja tidak mengeluarkan pajak dengan ukuran yang sebenarnya. 
Warno dan Ulul Fahmi: Pengaruh Tax Avoidance dan Biaya Agensi terhadap Nilai Perusahaan dengan Kualitas Audit sebagai Variabel Moderasi pada Perusahaan yang Terdaftar di Indeks LQ45 Periode 2016-2018

\section{Biaya Agensi}

Konflik keagenan menimbulkan biaya tersendiri yang harus dikeluarkan. Sartono (2000) yang dikutip dari Auditta et al, menjelaskan bahwa biaya yang harus dikeluarkan perusahaan guna meminimalisir terjadinya masalah agensi dinamakan biaya agensi, dimana biaya agensi bisa meliputi biaya pembuatan sistem informasi keuangan yang baik, biaya untuk auditor independen guna melakukan audit atas laporan keuangan perusahaan agar terhindar dari kecurangan, insentif kepada manajer, karyawan, pengangkatan dewan komisaris dari eksternal perusahaan agar bersifat netral, biaya untuk mengatur organisasi agar berjalan sesuai dengan tujuan (I Gede Auditta, Sutrisno, Achsin 2014: 287). Jensen dan Meckling (1976) membagi biaya keagenan menjadi 3 jenis, yaitu: 1.) The Monitoring Expenditures by the principal (Biaya Monitoring), 2.) Bonding Cost Expenditures by Agent (Bonding Cost), 3.) The Residual Loss (Kerugian Residual) (Jensen \& Meckling, 1976: 308).

Biaya agensi dalam perspektif Islam dapat tercermin dari ayat berikut yang artinya:

"Hai orang-orang yang beriman, janganlah kamu mengkhianati Allah dan

Rasul (Muhammad), dan (juga) janganlah kamu menghianati amanat-amanat yang dipercayakan kepadamu, sedang kamu mengetahui." (Q.S. An-Anfal ayat 27).

Pada ayat di atas menjelaskan bahwa hendaknya pekerja menghindari penipuan dan penghianatan yang telah diberikan kepadanya selama bekerja, seperti korupsi waktu, barang, ataupun aset yang berapapun nilainya (Uzaimi, 2017: 76). Seorang manajer atau agent selaku pengelola perusahaan telah mendapatkan amanah dari pemilik perusahaan untuk mengelola perusahaan guna mencapai tujuan perusahaan. Agent haruslah menjalankan amanah tersebut dengan baik dengan cara bekerja sesuai dengan koridor yang telah disepakati oleh keduanya.

\section{Kualitas Audit.}

Menurut Nugrahati (2014) yang dikutip dari Aswuri, mendefinisikan kualitas audit merupakan suatu kemungkinan yang bisa saja dijalankan auditor pada saat mendeteksi salah saji material ataupun ketika melaporkan salah saji material (Aswuri, 2017: 27). Menurut Owhoso et al (2002) yang dikutip dari khairunnisa et al, menjelaskan bahwa spesialisasi industri auditor akan menunjukkan hasil audit yang lebih meyakinkan (Khairunisa, Hapsari, \& Aminah, 2017: 41-42). KAP yang dianggap memiliki kualitas audit terbaik karena pengalaman kerjanya adalah KAP big four.

Kualitas audit dalam perspektif Islam diterangkan ayat berikut yang artinya:

"Hai orang-orang yang beriman, jika datang kepadamu orang fasik membawa suatu berita, maka periksalah dengan teliti agar kamu tidak menimpakan suatu musibah kepada suatu kaum tanpa mengetahui keadaannya yang menyebabkan kamu menyesal atas perbuatanmu itu" (Q.S Al-Hujurat Ayat 6).

Berdasarkan ayat di atas menjelaskan setiap orang dalam menyampaikan sesuatu hendaknya menelitinya terlebih dahulu supaya tidak ada orang lain yang mengalami kerugian. Kaitannya dengan audit adalah dalam hal pelaporan pemeriksaan atas laporan 
Warno dan Ulul Fahmi: Pengaruh Tax Avoidance dan Biaya Agensi terhadap Nilai Perusahaan dengan Kualitas Audit sebagai Variabel Moderasi pada Perusahaan yang Terdaftar di Indeks LQ45 Periode 2016-2018

keuangan yang diaudit, hendaknya sebelum memberikan opini auditor diharapkan dapat meneliti terlebih dahulu hasil dari pemeriksaannya sehingga hasil pemeriksaannya tidak merugikan perusahaan dan stakeholders yang berkepentingan terkait dengan hasil pemeriksaan itu.

\section{HIPOTESIS}

\section{Pengaruh Tax Avoidance Terhadap Nilai Perusahaan.}

Tax avoidance merupakan suatu tindakan untuk mengurangi beban pajak dengan mekanisme yang legal. Beban pajak yang besar dapat mengurangi laba yang diperoleh perusahaan. Sehingga manajer berusaha untuk membuat beban pajak yang dibayarkan tidak terlalu tinggi. Manager sebagai pengelola memiliki informasi yang lebih terkait dengan kondisi perusahaan yang sebenarnya. Berbeda dengan investor yang tidak terjun secara langsung dalam pengelolaan perusahaan. Sehingga investor akan cenderung melihat laporan keuangan untuk mengukur nilai perusahaan. Nilai perusahaan yang tinggi akan terlihat baik di mata pemegang saham karena dapat menggambarkan kesejahteraan pemegang saham. Menurut Chen dan Yuan (2004) yang dikutip dari Anggoro dan Septiani, beban pajak bisa digunakan sebagai ukuran untuk menentukan profitabilitas perusahaan (Anggoro \& Septiani, 2015: 3).

Namun untuk mengambil keputusan dengan melakukan tax avoidance perusahaan mengalami berbagai pertimbangan. Dimana dalam melakukan tax avoidance perusahaan harus melihat bahwa manfaat dari adanya tax avoidance haruslah lebih besar dibandingkan dengan beban ditanggung.

Tax avoidance tidak dapat dibenarkan oleh principal dan tidak selamanya diinginkan oleh principal. Tax avoidance dianggap sebagai salah satu cara untuk memanipulasi laporan keuangan artinya laporan keuangan tidak disajikan dengan sebenarnya. Selain itu juga akan menimbilkan risiko yang ada di perusahaan. Berdasarkan uraian tersebut peneliti mengambil rumusan hipotesis sebagai berikut:

$\mathrm{H}_{1}$ : Tax avoidance berpengaruh terhadap nilai perusahaan.

\section{Pengaruh Biaya Agensi Terhadap Nilai Perusahaan.}

Biaya agensi adalah biaya yang dikeluarkan akibat adanya konflik keagenan yang terjadi antara investor dengan manajer. Konflik keagenan timbul dikarenakan adanya asimetri informasi di antara ke dua belah pihak. Manajer cenderung untuk memiliki sifat oportunistik atau sifat yang menguntungkan dirinya sendiri. Biaya agensi bisa digunakan investor untuk melakukan monitoring terhadap kinerja dari manajer. Dengan adanya biaya agensi akan membuat manajer akan menjalankan pekerjaan sesuai dengan kontrak yang telah disepakati yang nantinya akan meningkatkan nilai perusahaan.

Menurut Chen et al (2004) yang dikutip dari Ghozali dan Adityamurti, menjelaskan bahwa melalui biaya agensi, principal bisa mengendalikan kerja dari manajemen yang bisa membuat nilai perusahaan tinggi seiring dengan tingginya biaya agensi yang dikeluarkan (Ghozali \& Adityamurti, 2017: 3). Sehingga berdasarkan uraian tersebut peneliti mengambil rumusan hipotesis sebagai berikut:

$\mathrm{H}_{2}$ : Biaya agensi berpengaruh terhadap nilai perusahaan. 
Warno dan Ulul Fahmi: Pengaruh Tax Avoidance dan Biaya Agensi terhadap Nilai Perusahaan dengan Kualitas Audit sebagai Variabel Moderasi pada Perusahaan yang Terdaftar di Indeks LQ45 Periode 2016-2018

Kualitas Audit dalam Mempengaruhi Hubungan Tax Avoidance dan Nilai Perusahaan.

Menurut Juliardi, kualitas audit merupakan ukuran yang digunakan untuk mengetahui tingkat kompetensi dan independensi dari kantor akuntan publik dalam melaksanakan proses audit terkait laporan keuangan yang menjadi objek pemeriksaannya guna memberikan kepastian bahwa kualitas nominal yang yang tercantum dalam laporan keuangan perusahaan benar-benar reliabel dan menunjukkan nilai yang sebenarnya (Wardani \& Juliani, 2018: 52). Diperlukannya hasil audit yang berkualitas karena auditor sendiri mempunyai tanggung jawab kepada banyak orang seperti stakeholders, masyarakat, bahkan pemerintah dan semua pihak yang berkepentingan terkait laporan keuangan perusahaan. Dengan kualitas audit yang baik maka manajer akan sulit untuk melakukan kecurangan dalam hal penghindaran pajak guna menguntungkan dirinya sendiri. Sehingga kemungkinan manajer melakukan perilaku tax avoidance menjadi kecil karena ada kualitas audit akan menghasilkan kenyataan terkait keadaan perusahaan yang sebenarnya sehingga akan berujung pada meningkatnya nilai perusahaan.

Menurut hasil penelitian Rusli (2016) yang dikutip dari Lestaria dan Ningrum, menghasilkan pengaruh kualitas audit dalam hubungan antara tax planning dengan nilai perusahaan dimana hasil penelitiannya kualitas audit dapat memperlemah hubungan antara tax planning terhadap nilai perusahaan (Lestaria \& Ningrum, 2018: 103-104). berdasarkan uraian tersebut peneliti mengambil rumusan hipotesis sebagai berikut.

$\mathrm{H}_{3}$ : Kualitas audit mempengaruhi hungan antara tax avoidance terhadap nilai perusahaan.

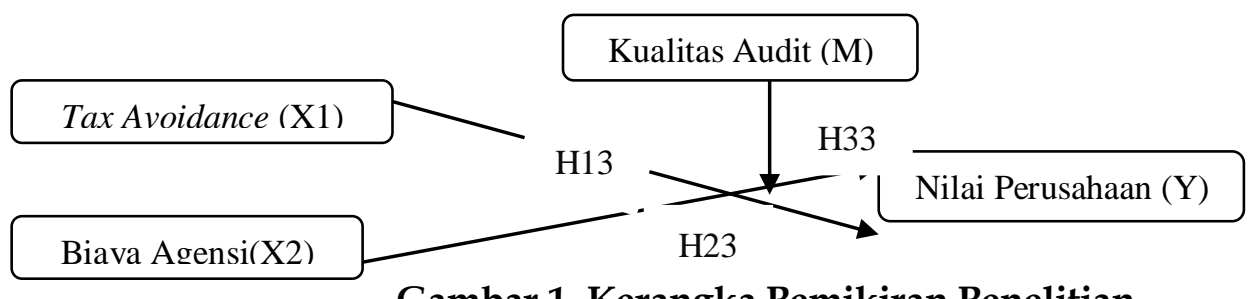

Gambar 1. Kerangka Pemikiran Penelitian

Berdasarkan landasan teori dan pengembangan hipotesis, model penelitian ini dapat digambarkan dengan Gambar 1.

\section{METODE}

Penelitian ini merupakan penelitian dengan pendekatan kuantitatif. Penelitian ini dianalisis menggunakan WarpPLS 4.0, dengan outer model, inner model, dan uji hipotesis. Penelitian ini digunakan untuk menguji adanya pengaruh dari variabel independen tax avoidance, biaya agensi terhadap variabel dependen yaitu nilai perusahaan. Dalam penelitian ini juga menguji adanya kualitas audit sebagai variabel yang memoderasi hubungan antara tax avoidance terhadap nilai perusahaan.

Penelitian ini data diperoleh menggunakan metode dokumentasi dan studi pustaka. Adapun data yang dipakai dipakai adalah data sekunder. Data sekunder dalam penelitian diperoleh dari website resmi Bursa Efek Indonesia (BEI) (https://www.idx.go.id), website resmi perusahaan yang dijadikan sampel dalam penelitian ini berupa laporan keuangan dan annual report, dan dari Indonesian Capital 
Warno dan Ulul Fahmi: Pengaruh Tax Avoidance dan Biaya Agensi terhadap Nilai Perusahaan dengan Kualitas Audit sebagai Variabel Moderasi pada Perusahaan yang Terdaftar di Indeks LQ45 Periode 2016-2018

Market Directory (ICMD). Sedangkan sampel penelitian ini diperoleh menggunakan tekhnik purposive sampling.

\section{Pengukuran Variabel}

Tax Avoidance

Adapun tax avoidance disini diukur menggunakan Cash Effective Tax Rate (Cash ETR) yang dikembangkan Dyreng et al. (2008) dengan formulasi sebagai Berikut (Decco Soerzawa, \& Yusmaniarti, 2018: 370):

Cash ETR $=\frac{\text { Pembambayaran Pajak }}{\text { Laba sebelum pajak }}$

\section{Biaya Agensi}

Dalam penelitian ini, peneliti menggunakan rasio Sales to Total Assets (STA) yang digunakan untuk mengukur biaya agensi. Dimana STA dihitung dengan Rumus:

STA $=\frac{\text { Total Penjwalan }}{\text { Total Aktiva }}$

\section{Nilai Perusahaan}

Nilai perusahaan disini diukur menggunakan tobin'sQ. Rasio ini dapat digunakan untuk mengukur kinerja perusahaan salah satunya untuk mengukur nilai perusahaan yang dapat memperlihatkan performa dari manajemen dalam mengelola perusahaan (Rahmawati, 2013: 3). Berikut ini adalah formula yang dipakai untuk menghitung nilai perusahaan menurut Smithers dan Wright (2007) (Prasetyorini, 2016: 186):

Tobin's $\mathrm{Q}=\frac{M V E+D E B T}{T A}$

Keterangan:

MVE = Nilai pasar dari jumlah lembar saham yang beredar yang diperoleh dari hasil perkalian antara jumlah saham yang beredar dengan closing price.

DEBT = Nilai total kewajiban perusahaan.

TA = Total aktiva perusahaan.

\section{Kualitas Audit}

Kualitas audit dalam penelitian ini diproyeksikan dengan variabel dummy. Untuk perusahaan yang diaudit oleh Kantor Akuntan Publik (KAP) big four akan diberikan angka 1. Sedangkan untuk perusahaan yang diaudit oleh KAP non big four akan diberikan angka 0. KAP big four disini adalah delloite, Pricewaterhousecoopers (Pwc), KMPG, Ernest \& Young (EY).

\section{HASIL DAN PEMBAHASAN}

Penelitian ini memakai populasi perusahaan yang tergabung dalam Indeks LQ45 pada periode 2016-2018. Sampel perusahaan telah dipilih berdasarkan kriteria-kriteria yang telah ditetapkan sebanyak 30 sampel perusahaan. Berikut ini merupakan tabel penentuan kriteria untuk mendapatkan sampel yang digunakan dalam penelitian.

Tabel 1. Kriteria Pemilihan sampel

\begin{tabular}{clc}
\hline No. & Kriteria & Jumlah \\
\hline 1 & Perusahaan yang terdaftar di LQ45 pada periode 2016 - 2018. & 60 \\
\hline 2 & Perusahaan yang tidak terdaftar di LQ45 pada periode 2016 - & $(25)$ \\
\hline
\end{tabular}


Warno dan Ulul Fahmi: Pengaruh Tax Avoidance dan Biaya Agensi terhadap Nilai Perusahaan dengan Kualitas Audit sebagai Variabel Moderasi pada Perusahaan yang Terdaftar di Indeks LQ45 Periode 2016-2018

2018 secara berturut-turut.

3 Laporan keuangan tidak disajikan dengan mata uang rupiah. (4)

$4 \quad$ Perusahaan yang memiliki laba sebelum pajak negatif.

Perusahaan yang masuk kriteria. $\quad 30$

Total Perusahaan yang menjadi sampel penelitian $30 \times 3 \quad 90$ tahun.

Sumber: Data Sekunder diolah 2020

Berdasarkan hasil uji analisis data berupa uji inner model, outer model, dan uji hipotesis dari penelitian ini menghasilkan beberapa hal berikut yang tercantum dalam tabel 2,3, dan 4:

Tabel 2. Uji Outer Model: Konvergent Validity, Diskriminant Validity, dan Composite Reability

\begin{tabular}{lccc}
\hline & Indeks & $\begin{array}{c}\text { Rule of } \\
\text { Thumbs }\end{array}$ & Keterangan \\
\hline $\begin{array}{l}\text { Kovergent Validity } \\
\text { Nilai Loading }\end{array}$ & 1 & $>0.7$ & Memenuhi kriteria \\
\hline $\begin{array}{l}\text { Discriminant Validity } \\
\text { AVE }\end{array}$ & 1 & $>0.5$ & $\begin{array}{l}\text { Memenuhi Kriteria } \\
\text { Akar AVE }\end{array}$ \\
$\begin{array}{lccc}\text { Composite Reability } \\
\text { Cronbach alpha }\end{array}$ & 1 & $>0.7$ & Memenuhi Kriteria \\
\hline
\end{tabular}

Sumber: Output WarpPLS 4.0

Tabel 3. Uji Inner Model: Model Fit, $R$-Square, $Q$-Square

\begin{tabular}{lllll}
\hline & \multicolumn{1}{c}{ Indeks } & \multicolumn{1}{c}{ P-Value } & Kriteria & \multicolumn{1}{c}{ Keterangan } \\
\hline AARS & 0,457 & $<0,001$ & $\mathrm{P}<0,05$ & Diterima \\
\hline APC & 0,278 & $<0,001$ & $\mathrm{P}<0,05$ & Diterima \\
\hline ARS & 0,475 & $<0,001$ & $\mathrm{P}<0,05$ & Diterima \\
\hline AVIF & 1.377 & & AVIF $<5$ & Diterima \\
\hline Model Fit & & & & \\
\hline$Q$-Square & 0.515 & & & \\
\hline R-Square & 0,475 & & &
\end{tabular}

Sumber: Output WarpPLS 4.0

Tabel 4. Uji Hipotesis

\begin{tabular}{lcccc}
\hline \multicolumn{1}{c}{ Variabel } & P-value & Kriteria & $\mathrm{B}$ & Hipotesis \\
\hline CashETR * Tobin'sQ & 0.038 & $\mathrm{P}<0.05$ & -0.14 & Diterima \\
\hline STA * Tobin'sQ & $<0.001$ & $\mathrm{P}<0.05$ & 0.649 & Diterima \\
\hline Bigfour*CashETR* Tobin'sQ & 0.299 & $\mathrm{P}<0.05$ & 0.04 & Ditolak \\
\hline${ }^{*}$ sig: 5\% & & & & \\
\hline Sumber: Output WarpPLS 4.0 & & & &
\end{tabular}

\section{Pengaruh Tax Avoidance Terhadap Nilai Perusahaan.}

Hasil penelilian ini mendukung hipotesis pertama bahwa tax avoidance memiliki pengaruh yang signifikan terhadap nilai perusahaan yang diproyeksikan dengan tobins'Q dalam kurun waktu 2016 hingga 2018. Hal tersebut bisa terlihat dari nilai $p$-value yang menunjukkan angka $\mathrm{P}=0.038$ yang mana nilai tersebut masih berada di dalam standar atau kriteria yang ditentukan yaitu $<0.05$. Berdasarkan hasil uji yang dilakukan 
Warno dan Ulul Fahmi: Pengaruh Tax Avoidance dan Biaya Agensi terhadap Nilai Perusahaan dengan Kualitas Audit sebagai Variabel Moderasi pada Perusahaan yang Terdaftar di Indeks LQ45 Periode 2016-2018

menunjukkan tax avoidance mempunyai pengaruh negatif terhadap nilai perusahaan yang ditunjukkan oleh nilai koefisien beta sebesar -0,142. Artinya setiap terjadi kenaikan CashETR sebesar satu satuan maka akan menurunkan nilai perusahaan sebesar $14,2 \%$. Sehingga semakin tinggi tax avoidance yang dilakukan oleh manajer akan menurunkan nilai perusahaan. Adanya pengaruh negatif tax avoidance terhadap nilai perusahaan karena tax avoidance dianggap sebagai salah satu kecurangan yang disebabkan oleh laporan keuangan yang menyesatkan yang akan mempengaruhi keputusan investor dalam menanamkan modalnya kepada perusahaan. Tax avoidance menyalahi tujuan yang sebenarnya dari peraturan perpajakan sehingga apabila perilaku tax avoidance terbongkar akan mengancam nama baik, citra, reputasi, dan keberlangsungan perusahaan.

Penelitian ini sejalan dengan penelitian yang dilakukan oleh Panggabean (2018), Lestari dan ningrum (2018) dimana dalam penelitian mereka menghasilkan tax avoidance berpengaruh secara negatif terhadap nilai perusahaan. Artinya semakin tinggi nilai tax avoidance akan menurunkan nilai perusahaan.

Namun penelitian ini tidak sejalan dengan penelitian yang dilakukan oleh Anggoro dan Septiani (2015), dalam penelitiannya menghasilkan bahwa penghindaran pajak berpengaruh positif terhadap nilai perusahaan. Artinya semakin tinggi perusahaan melakukan penghindaran pajak maka nilai perusahaan akan meningkat.

\section{Pengaruh Biaya Agensi Terhadap Nilai Perusahaan.}

Hipotesis kedua dalam penelitian ini yaitu biaya agensi berpengaruh terhadap nilai perusahaan. Biaya Agensi dalam penelitian ini diproyeksikan dengan STA (Sales to Total Asset). Berdasarkan hasil penelitian menunjukkan bahwa biaya agensi berpengaruh signifikan terhadap nilai perusahaan dalam kurun waktu 2016 sampai tahun 2018. Hal tersebut bisa dilihat dari nilai $p$-value yang menghasilkan angka $p<0.001$. Berdasarkan hasil uji yang dilakukan diperoleh hasil biaya agensi mempunyai pengaruh positif terhadap nilai perusahaan yang ditunjukkan oleh nilai koefisien beta sebesar 0,649. Artinya setiap terjadi kenaikan Sales to Total Asset (STA) sebesar satu satuan maka akan menurunkan nilai perusahaan sebesar $64,9 \%$. Hal ini menunjukkan bahwa semakin tinggi biaya agensi yang dikeluarkan oleh perusahaan maka semakin tinggi nilai perusahaan. Semakin tinggi biaya agensi yang harus dikeluarkan perusahaan untuk mengawasi dan mengontrol kinerja manajer agar berjalan sesuai dengan kontrak yang telah dilakukan maka akan meningkatkan nilai perusahaan. Hasil penelitan ini mendukung teori agensi yang menyatakan terjadinya perbedaan kepentingan yang terjadi antara manajer (agent) dengan pemilik perusahaan (principal) dapat menyebabkan adanya biaya agensi yang dikeluarkan. Adanya biaya agensi akan membuat pemilik perusahaan bisa mengawasi kinerja manajer agar sesuai dengan kontrak atau kesepakan yang terjadi diantara keduanya. Kinerja manajer akan baik dan sesuai dengan aturan sehingga akan memberikan kontribusi yang baik pada kinerja perusahaan yang nantinya akan berdampak pada meningkatnya nilai perusahaan.

Hasil penelitian ini sejalan dengan penelitian yang dilakukan oleh Adityamurti dan Ghozali (2017) dan Meganingrum (2018) yang menyatakan bahwa biaya agensi memiliki pengaruh positif signifikan terhadap nilai perusahaan dimana perusahaan yang memiliki biaya agensi lebih besar akan cenderung memiliki nilai perusahaan yang lebih tinggi. Namun penelitian ini berbanding terbalik dengan hasil penelitian yang dilakukan 
Warno dan Ulul Fahmi: Pengaruh Tax Avoidance dan Biaya Agensi terhadap Nilai Perusahaan dengan Kualitas Audit sebagai Variabel Moderasi pada Perusahaan yang Terdaftar di Indeks LQ45 Periode 2016-2018

oleh Kusuma Negara ( 2019) yang memperoleh hasil variabel biaya agensi berpengaruh negatif signifikan terhadap nilai perusahaan.

Pengaruh Kualitas Audit dalam Memperkuat/Memperlemah Hubungan Antara Tax avoidance Terhadap Nilai Perusahaan.

Kualitas audit dalam penelitian ini diproyeksikan dengan KAP big four. Berdasarkan hasil penelitian yang menunjukkan bahwa kualitas audit tidak mampu memoderasi hubungan yang terjadi antara tax avoidance terhadap nilai perusahaan. Hal tersebut bisa terlihat dari nilai $p$-value yang menunjukkan angka $\mathrm{P}=0.299$ yang mana masih di atas standar minimal dari kriteria yang ditentukan yaitu $<0.05$. Hal ini menunjukkan apabila perusahaan diaudit oleh KAP big four maka tidak akan mengurangi perilaku oportunistik agent dalam dalam melakukan praktik tax avoidance yang akan mengakibatkan turunnya nilai perusahaan. Sehingga semakin baik reputasi dari auditor yang mengaudit perusahaan tidak dapat menahan manajer untuk melakukan praktik tax avoidance untuk meningkatkan nilai perusahaan.

Penelitian ini sejalan dengan penelitian yang dilakukan oleh Lestaria dan Ningrum (2018) yang menghasilkan kualitas audit tidak mempengaruhi hubungan antara tax avoidance terhadap nilai perusahaan. Artinya baik atau buruknya kualitas audit suatu perusahaan tidak akan mempengaruhi hubungan antara tax avoidance terhadap nilai perusahaan. Perusahaan yang diaudit oleh kantor akuntan publik yang mempunyai reputasi tinggi, dan kompetensi yang sudah tidak diragukan lagi belum mampu untuk mengurangi tindakan penghindaran pajak yang dilakukan oleh perusahaan. Penelitian ini belum bisa membuktikan kualitas audit dapat mempengaruhi hubungan yang terjadi antara tax avoidance terhadap nilai perusahaan.

\section{KESIMPULAN}

Hasil dari penelitian ini Variabel tax avoidance berpengaruh negatif signifikan terhadap nilai perusahaan. Hal ini menunjukkan bahwa semakin tinggi tax avoidance yang dilakukan perusahaan maka akan menurunkan nilai perusahaan. Variabel biaya agensi berpengaruh positif signifikan terhadap nilai perusahaan. Hal ini menunjukkan bahwa semakin tinggi biaya agensi yang dikeluarkan perusahaan maka akan meingkatkan nilai perusahaan. Variabel kualitas audit tidak memoderasi hubungan yang terjadi antara tax avoidance terhadap nilai perusahaan. Artinya disini semakin baik atau buruk kualitas audit yang dilakukan oleh KAP bigfour tidak dapat meningkatkan atau menurunkan tindakan tax avoidance yang dilakukan oleh perusahaan.

\section{DAFTAR PUSTAKA}

Adityamurti Enggar, Imam Ghozali. (2017). Pengaruh Penghindaran Pajak Terhadap Nilai Perusahaan. Diponegoro Journal Of Accounting, Vol. 6, No. 3. h. 3.

Anggoro, S. T., \& Septiani, A. (2015). Analisis Pengaruh Perilaku Penghindaran Pajak Terhadap Nilai Perusahaan Dengan Transparansi Sebagai Variabel Moderating. Diponegoro Journal Of Accounting, Vol. 4, No. 4. h. 3.

Apsari, L., \& Setiawan, P. E. (2018). Pengaruh Tax Avoidance terhadap Nilai Perusahaan dengan Kebijakan Dividen sebagai Variabel Moderasi. E-Jurnal Akuntansi Universitas 
Warno dan Ulul Fahmi: Pengaruh Tax Avoidance dan Biaya Agensi terhadap Nilai Perusahaan dengan Kualitas Audit sebagai Variabel Moderasi pada Perusahaan yang Terdaftar di Indeks LQ45 Periode 2016-2018

Udayana, Vo. 23, No. 3.

Ary Wirajaya, A. (2013). Pengaruh Struktur Modal, Profitabilitas Dan Ukuran Perusahaan Pada Nilai Perusahaan. E-Jurnal Akuntansi, Vol. 4, No. 2. h. 361.

Auditta, I. Gede, Sutrisni, M. Achsin. (2014). Pengaruh Agency Cost Terhadap Kebijakan Dividen. Jurnal Aplikasi Manajemen, Vol. 12, No. 2. h. 278.

Az-Zuhaili, W. (2016). Tafsir Al-Munir Aqidah, Syariah, Manhaj. Jakarta: Gema Insani.

Basri, Y., Agusti, R., \& Adelina, S. (2014). Pengaruh Rasio Likuiditas, Leverage Dan Profitabilitas Terhadap Nilai Perusahaan Pada Industri Barang Konsumsi Yang Terdaftar Di Bursa Efek Indonesia Tahun 2010-2012. Jurnal Online Mahasiswa Fakultas Ekonomi Universitas Riau, Vol. 1, No. 2. h. 1

Febriana, E. , Djumahir, \& Djawahir, A. (2016). Pengaruh Struktur Modal, Kebijakan Dividen, Ukuran Perusahaan,Kepemilikan Saham Manajerial Dan Profitabilitas Terhadap Nilai Perusahaan (Studi Pada Perusahaan Manufaktur Yang Terdaftar Di BEI Pada 2011-2013). Jurnal Ekonomi Bisnis, Vol. 21, No. 2. h. 1.

Hamka. (2015). Tafsir Al-Azhar. Jakarta: Gema Insani.

Jensen, M. C., \& Meckling, W. H. (1976). Theory of the firm: Managerial behavior, agency costs and ownership structure. Journal of Financial Economics, h. 308.

Khairunisa, K., Hapsari, D. W., \& Aminah, W. (2017). Pengaruh Kualitas Audit, Corporate Social Responsibility dan Ukuran Perusahaan Terhadap Tax Avoidance. Journal Riset Akuntansi Kontemporer (JRAK), Vol. 9, No. 1. h. 41-42.

Krisna, A. M. (2019). Pengaruh Kepemilikan Institusional dan Kepemilikan Manajerial pada Tax Avoidance dengan Kualitas Audit sebagai Variabel Pemoderasi. Jurnal Ekonomi, Bisnis Dan Akuntansi, Vol. 18, No. 2. h. 3.

Megarani, N. Ahmad Fauzi, Warno. (2019). The effect of tax planning, company value, and leverage on income smoothing practices in companies listed on Jakarta Islamic Index. Journal of Islamic Accounting and Research. Vol. 1. No. 1. h. 148.

Nanik Lestaria, Selvy Agita N. (2018). Pengaruh Manajemen Laba dan Tax Avoidance terhadap Nilai Perusahaan dengan Kualitas Audit sebagai Variabel Moderasi. Journal of Applied Accounting and Taxation, Vol. 3, No. 1. h. 103-104.

Negara, I. K. (2019). Analisis Pengaruh Kebijakan Dividen Dan Leverage Terhadap Nilai Perusahaan Dengan Agency Cost Sebagai Variabel Intervening Pada Emiten Manufaktur Sektor Industri Barang Konsumsi Yang Terdaftar Di Bursa Efek Indonesia. Jurnal Riset Manajemen, Vol. 19, No. 1. h. 64.

Panggabean, M. R. (2018). Pengaruh Corporate Social Responsibility , Ukuran Perusahaan, Struktur Modal Dan Tax Avoidance Terhadap Nilai Perusahaan. Jurnal Kajian Bisnis, Vol. 26, No. 1. h. 82. 
Warno dan Ulul Fahmi: Pengaruh Tax Avoidance dan Biaya Agensi terhadap Nilai Perusahaan dengan Kualitas Audit sebagai Variabel Moderasi pada Perusahaan yang Terdaftar di Indeks LQ45 Periode 2016-2018

Pohan, C. A. (2013). Manajemen Perpajakan Strategi Perencanaan dan Bisnis. Jakarta: Gramedia Pustaka Utama.

Prasetyorini, Bhekti. F. (2016). Pengaruh Ukuran Perusahaan, Leverage, Dan Profitabilitas Terhadap Nilai Perusahaan. E-Jurnal Manajemen Universitas Udayana, Vol. 5, No. 7. h. 186.

Purwono, H. (2010). Dasar-Dasar Perpajakan dan Akuntansi Pajak. Jakarta: Erlangga.

Rahmawati, A. D. (2013). Pengaruh Ukuran Perusahaan, Profitabilitas, Struktur Modal, dan Keputusan Investasi Terhadap Nilai Perusahaan (Studi pada Perusahaan Sektor Properti, Real Estate, dan Building Construction yang Terdaftar di Bursa Efek Indonesia (BEI) Periode 2010-2013). Jurnal Administrasi Bisnis (JAB), Vol. 23, No. 2. h. 3.

Sintyawati, N., \& Dewi, M. (2018). Pengaruh Kepemilikan Manajerial, Kepemilikan Institusional dan Leverage terhadap Biaya Keagenan pada Perusahaan Manufaktur. E-Jurnal Manajemen Universitas Udayana, Vol. 7, No. 2. h. 995.

Soerzawa Decco, Yusmaniarti, dan Chaerul Suhendra. (2018). Influence Of Tax Avoidance On Company Value With Laverage As The Moderating Variable. BILANCIA, Vol. 2, No. 4. h. 375

Sugianto, Danang. "Mengenal Soal Penghindaran Pajak yang Dituduhkan ke Adaro". 05 Juli 2019. https:// m.detik.com/finance/berita-ekonomi-bisnis/d-4612708/mengenalsoal-penghindaran-pajak-yang-dituduhkan-keadaro diakses pada 19 Desember 2019 pukul 14.51 WIB. diakses pada 19 Desember 2019 pukul 14.51 WIB.

Sugiyarti, Sinta M., \& Purwanti. L. (2017). Pengaruh Intensitas Aset Tetap, Pertumbuhan Penjualan Dan Koneksi Politik Terhadap Tax Avoidance (Studi Kasus Pada Perusahaan Manufaktur Yang Terdaftar Di Bursa Efek Indonesia Tahun 2012-2016). Jurnal Riset Akuntansi dan Keauangan (JRAK), Vol. 5, No. 3. h. 1625.

Undang-Undang Republik Indonesia Nomor 28 Tahun 2007 Tentang Ketentuan Umum Dan Tata Cara Perpajakan Pasal 1 Ayat 1.

Uzaimi, A. (2017). Teori Keagenan Dalam Perspektif Islam. Jurnal Ilmiah Akuntansi Dan Finansial Indonesia, Vol. 1, No. 76. h. 76.

Wardani, D. K., \& Juliani, J. (2018). Pengaruh Tax Avoidance Terhadap Nilai Perusahaan Dengan Corporate Governance Sebagai Variabel Pemoderasi. Nominal, Barometer Riset Akuntansi Dan Manajemen, Vol. 7, No. 2. h. 52. 